\title{
ACTIVITY OF DEHYDROGENASES AND ENZYMES OF NITROGEN METABOLISM IN RUMEN MUCOSA AND LIVER OF STEERS FED MONENSIN
}

\author{
G. I. KALACNJUK ${ }^{1}$, M. MAROUNEK ${ }^{2 *}$, M. G. GERASYMIV ${ }^{1}$ \\ O. G. SAVKA ${ }^{2}$, L. G. KALAČNJUK ${ }^{3}$ \\ 1Ukrainian Research Institute of Physiology and Biochemistry of Farm Animals, Lvov
2Institute of Animal Physiology and Genetics, Czech Academy of Sciences,
10400 Prague 10-Uhřiněves
${ }^{3}$ Institute of Molecular Biology and Genetics, Ukrainian Academy of Sciences, Kiev
}

Received November 11, 1992

\begin{abstract}
Kalačnjuk G. I., M. Marounek, M. G. Gerasymiv, O. G. Savka, L. G. Kalačnjuk: Activity of Dehydrogenases and Enzymes of Nitrogen Metabolism in Rumen Mucosa and Liver of Steers Fed Monensin. Acta vet. Brno, 62, 1993: $127-131$.

The effect of monensin on activity of intracellular enzymes of tissues was determined in ten steers fed hay, silage and concentrate. Five steers received monensin in amount of $0.5 \mathrm{mg}$ per $1 \mathrm{~kg}$ of live weight per day. After 10 months steers were slaughtered and activity of dehydrogenases and enzymes of nitrogen metabolism assayed in mitochondrial and cytoplasmic fraction of cells of rumen mucosa and liver. Monensin had no consistent effect on activity of nine enzymes examined (lactate dehydrogenase, malate dehydrogenase, $\alpha$-ketoglutarate dehydrogenase, glutamate dehydrogenase, glutamin synthetase, arginase, ornithine carbamoyltransferase, aspartate aminotransferase and alanine aminotransferase). The results indicate that long-term inclusion of monensin into diet of steers has no damaging effect on cells of rumen mucosa and liver.
\end{abstract}

Monensin, enzyme, rumen mucosa, liver

Ionophores are fed to ruminants because they improve feed efficiency and increase weight gains. Numerous studies have demonstrated that ionophores alter rumen metabolism (review Bergen and Bates 1984). Typical ionophore-induced effects include the increase of propionate production in the rumen and the decrease of production of acetate, butyrate and methane. Similar changes in fermentation stoichiometry were observed in ruminant hindgut (Marounek et al. 1990). Recent research provided evidence for an effect of ionophores on metabolism in ruminants independent of alterations in rumen and hindgut microbial metabolism. Experiments of Davis on (1984) showed that $36-40 \%$ of radiolabelled monensin was absorbed from the gastrointestinal tract of calves and Armstrong and Spears (1988) supplied data on changes of intermediary metabolism of heifers following intravenous ionophore administration.

In this paper we examined the effect of long-term monensin feeding on activity of nine intracellular enzymes in rumen mucosa and liver of steers.

\section{Materials and Methods}

Ten crossbred steers, one year old at the beginning of experiment were divided into two groups according to feed additive treatment. Steers were individually housed and kept on a diet consisting of concentrate $(3.5 \mathrm{~kg})$ and hay and silage ad libitum. Five steers received monensin in amount

* Corresponding author 
of $0.5 \mathrm{mg}$ per $1 \mathrm{~kg}$ of live weight per day. After 10 months steers were slaughtered and samples of rumen mucosa and liver tissue collected from monensin-fed and control steers. Rumen tissue was removed from the ventral sac, washed with tap water, $0.9 \% \mathrm{NaCl}, 1 \%$ Triton $\mathrm{X}-100$ (Serva) and again with $0.9 \% \mathrm{NaCl}$ to eliminate digesta residues and bacteria from the surface. Muscle tissue was removed as completely as possible. Rumen epithelium with underlying connective tissue $(50 \mathrm{~g})$ and liver tissue $(10 \mathrm{~g})$ were frozen in liquid nitrogen and stored until analyzed. Tissue samples were pulverized prior to cell breakage by homogenization in a homogenizer of the PotterElvehjem type. Mitochondrial and microsomal-cytoplasmic fraction of cells were obtained by differential centrifugation using procedure of Hogeboom (1955). Nine enzymes were assayed at $37^{\circ} \mathrm{C}$ in extracts, which were prepared by method of Morton (1955). Lactate dehydrogenase (LDH) was assayed according to the method of Kornberg (1955), malate dehydrogenase (MDH) according to Ochoa (1955), $\alpha$-ketoglutarate dehydrogenase (KGDH) according to Kaufman (1955), glutamate dehydrogenase (GDH) according to Strecker (1955), glutamin synthetase (GS) according to Elliot (1955), arginase (A) according to Greenberg (1955) and ornithine carbamoyl-transferase (OCT) according to Grisolia (1955). Aspartate aminotransferase (AST) and alanine aminotransferase (ALT) were assayed using commercial Bio-la-tests (Lachema, Brno, Bohemia).

Lactate dehydrogenase (E.C.1.1.1.27) belongs to principal enzymes of carbohydrate metabolism in tissues. Malate dehydrogenase (E.C.1.1.1.40) and $\alpha$-ketoglutarate dehydrogenase ( $\alpha$-ketoglutaric dehydrogenase system) are enzymes of the citric cycle. Glutamate dehydrogenase (E.C.1.4.1.3) and glutamin synthetase (E.C.6.3.1.2.) are ammonia assimilating enzymes. Arginase (E.C.3.5.3.1) and ornithine carbamoyltransferasse (E.C.2.1.3.3.) function in the urea cycle. Aspartate aminotransferase (E.C.2.6.1.1) and alanine aminotransferase (E.C.2.6.1.2) play an important role in amino acid metabolism.

\section{Results}

The results have been summarized in Table 1 and Table 2. Table 1 presents activities of nine enzymes in the mitochondrial fraction of cells of rumen mucosa and liver in control and monensin-fed steers. Table 2 shows corresponding values found in the microsomal-cytoplasmic fraction of cells. A third of the differences between monensin-fed and control steers reached statistical significance. There was, however, no consistent effect of monensin on activity of enzymes examined. Furthermore, in most cases differences were relatively small.

Levels of $\mathrm{LDH}$ and $\mathrm{MDH}$ in mitochondrial fraction of rumen mucosa were 2-4 times higher than in analogous fraction of liver. Activity of $\mathrm{LDH}$ in cytosolic fraction of rumen mucosa was more than 20-times higher than in hepatocytes. On the other hand, activities of KGDH and OCT were higher in liver than in rumen mucosa.

\section{Discussion}

Initial research conducted with ionophores focused mainly on their application in the feedlot industry and on their ruminal effects. At present, there are several reports on the influence of ionophores on intermediary metabolism of nitrogen and carbohydrates in ruminants. Armstrong and Spears (1988) administered monensin intravenously to heifers and studied their metabolic response. Monensin increased plasma glucose level, free fatty acids and serum insulin in treated animals. Plasma glucose was increased also in monensin-fed cows in experiments of Grings and Males (1988). Addition of lasalocid to the diet of lambs reduced the concentration of $\beta$-hydroxybutyrate in serum, while free fatty acids and glucose did not change (Fegeros et al., 1989). Benz et al. (1989) found changes in concentrations of intermediary metabolites in bovine hepatic tissue (glyceraldehyde 3-phosphate, pyruvate, fructose-1, 6-diphosphate and 
Table 1

Activities $^{1}$ of enzymes in the mitochondrial fraction of cells of rumen mucosa and liver in control and monensin-fed steers

\begin{tabular}{|c|c|c|c|c|}
\hline \multirow{3}{*}{ Enzyme? } & \multicolumn{4}{|c|}{ Tissue } \\
\hline & \multicolumn{2}{|c|}{ Rumen mucosa } & \multicolumn{2}{|c|}{ Liver } \\
\hline & Control & Monensin & Control & Monensin \\
\hline 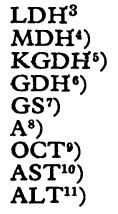 & $\begin{aligned} 38.2 & \pm 3.9 \\
2904 & \pm 451 \\
7.2 & \pm 0.4 \\
8.5 & \pm 0.5 \\
2.3 & \pm 0.2 \\
37.0 & \pm 6.1 \\
31.4 & \pm 10.2 \\
9.4 & \pm 2.1 \\
5.6 & \pm 0.3\end{aligned}$ & $\begin{aligned} 28.4 & \pm 2.9 * \\
2299 & \pm 444 \\
6.4 & \pm 0.6 \\
8.0 & \pm 1.2 \\
2.0 & \pm 0.2 \\
39.8 & \pm 10.5 \\
20.8 & \pm 3.7 \\
6.8 & \pm 0.9 \\
4.6 & \pm 0.9\end{aligned}$ & $\begin{aligned} 12.2 & \pm 1.1 \\
702 & \pm 37 \\
12.3 & \pm 1.9 \\
24.8 & \pm 4.3 \\
0.5 & \pm 0.1 \\
11.8 & \pm 0.7 \\
410 & \pm 41 \\
99.1 & \pm 6.7 \\
3.7 & \pm 0.4\end{aligned}$ & $\begin{array}{c}14.6 \pm 1.8 \\
895 \pm 27^{*} \\
12.1 \pm 1.7 \\
21.2 \pm 3.8 \\
0.2 \pm 0.1^{*} \\
10.3 \pm 1.5 \\
424 \pm 43 \\
90.6 \pm 2.3^{*} \\
5.8 \pm 0.6^{*}\end{array}$ \\
\hline
\end{tabular}

1) Per $1 \mathrm{mg}$ of protein.

2) See "Material and Methods" for explanation.

3) $\mathrm{nmol} \mathrm{NADH} / \mathrm{min}$.

) $n$ mol NADP/min.

5) $\mathrm{nmol} \mathrm{NAD} / \mathrm{min}$.

6) $\mathrm{nmol} \mathrm{NADPH} / \mathrm{min}$.

7) nmol $\gamma$-glutamylhydroxamate/h.

8) $\mathrm{nmol}$ urea/min.

D) $\mathrm{nmol} \mathrm{NH} / \mathrm{min}$.

10) nmol oxaloacetate/min.

11) mmol pyruvate/min.

* Significantly different from control at $\mathbf{P}<0.05$

Table 2

Activities $^{1}$ ) of enzymes in the microsomal-cytoplasmic fraction of cells of rumen mucosa and liver in control and monensin-fed steers

\begin{tabular}{|c|c|c|c|c|}
\hline \multirow{3}{*}{ Enzyme $^{2}$} & \multicolumn{4}{|c|}{ Tissue } \\
\hline & \multicolumn{2}{|c|}{ Rumen mucosa } & \multicolumn{2}{|c|}{ Liver } \\
\hline & Control & Monensin & Control & Monensin \\
\hline $\begin{array}{l}\mathrm{LDH}^{3} \text { ) } \\
\mathrm{MDH}^{4} \text { ) } \\
\mathrm{KGDH}^{5} \text { ) } \\
\mathrm{GDH}^{6} \text { ) } \\
\mathrm{GS}^{7} \text { ) } \\
\mathrm{A}^{8} \text { ) } \\
\mathrm{OCT}^{9} \text { ) } \\
\mathrm{AST}^{10} \text { ) } \\
\mathrm{ALT}^{11} \text { ) }\end{array}$ & $\begin{array}{c}563 \pm 37 \\
266 \pm 56 \\
2.8 \pm 0.3 \\
5.6 \pm 1.0 \\
0.14 \pm 0.24 \\
203 \pm 42 \\
8.5 \pm 2.0 \\
19.7 \pm 1.5 \\
10.3 \pm 0.7\end{array}$ & $\begin{array}{c}364 \pm 47^{*} \\
259 \pm 33 \\
3.4 \pm 0.4 \\
6.7 \pm 1.0 \\
0.16 \pm 0.01 \\
168 \pm 13 \\
8.6 \pm 0.8 \\
15.5 \pm 1.3^{*} \\
10.4 \pm 1.1\end{array}$ & $\begin{aligned} 21.6 & \pm 2.6 \\
252 & \pm 33 \\
18.2 & \pm 2.6 \\
6.9 & \pm 0.5 \\
2.4 & \pm 0.2 \\
228 & \pm 21 \\
291 & \pm 28 \\
20.9 & \pm 1.5 \\
2.5 & \pm 0.2\end{aligned}$ & $\begin{array}{r}16.7 \pm 2.3^{*} \\
356 \pm 54^{*} \\
23.1 \pm 2.1^{*} \\
6.0 \pm 1.6 \\
2.5 \pm 0.1 \\
209 \pm 12 \\
337 \pm 26^{*} \\
19.7 \pm 1.1 \\
3.6 \pm 0.1\end{array}$ \\
\hline
\end{tabular}

For $\left.{ }^{1}\right)^{-11}$ ) see Table 1 .

* Significantly different from control at $\mathrm{P}<0.05$

dihydroxyacetone phosphate) that suggest alterations in carbohydrate metabolism favouring gluconeogenesis in steers fed monensin or lasalocid. Hepatic glycogen levels were not affected by the treatment.

Reports on the effect of ionophores on intermediary nitrogen metabolism of ruminants are more scarce. Marounek et al. (1989) found that total protein and activitres of aminotransferases in serum of monensin-fed and control calves were similar. Van Ryssen (1991) however, found an increased level of aspartate aminotransferase in plasma of sheep receiving monensin in feed.

In general, ionophores may alter tissue metabolism through their effect on ion concentration in cells and/or through an indirect mechanism involving $\beta$-adrenergic stimulation (Pressman and Fahim 1982). At high intakes, monen- 
sin can be very toxic. The results provided herein document that monensin added in an amount of $0.5 \mathrm{mg}$ per $1 \mathrm{~kg}$ of live weight of steers per day has no consistent effect on activity of dehydrogenases and enzymes of nitrogen metabolism in rumen mucosa and liver. It can be concluded that monensin added at recommended levels to the feed of steers has no long-term damaging or toxic effects on these tissues.

\section{Aktivita dehydrogenáz a enzymů metabolismu dusíku v bachorové} mukóze a játrech býků krmených dávkou s přídavkem monensinu

Zjištovali jsme účinek monensinu na aktivitu intracelulárních enzymů $v$ tkáních býků krmených senem, siláží a koncentrátem. Pět býků dostávalo monensin $\mathrm{v}$ množství $0,5 \mathrm{mg} / \mathrm{kg}$ živé hmotnosti denně. Pět býkủ bylo kontrolních. Býci byli po 10 měsících poraženi a $\mathrm{v}$ mitochondriální a cytoplazmatické frakci buněk bachorové mukózy a jater byly stanoveny aktivity dehydrogenáz a enzymů metabolismu dusíku. Nebyl zjištěn systematický účinek monensinu na aktivitu 9 sledovaných enzymů (laktátdehydrogenázy, malátdehydrogenázy, $\alpha$-ketoglutarátdehydrogenázy, glutamátdehydrogenázy, glutaminsyntetázy, arginázy, ornithinkarbamoyltransférázy, aspartátaminotransferázy a alaninaminotransferázy). Výsledky ukazují, že ani dlouhodobé zkrmování monensinu býkủm nemá škodlivý účinek na buňky uvedených tkání.

\section{Активность энзимов азотфиксирующих реакций и дегидрогеназ сүбклеточных фракций и свободные аминокислоты тканей под действием монензима у жвачных}

Не отмечено также достоверных межгрупповых различий в активностях глутаминсинтетазы, аргиназы, орнитинкарбомоилтрансферазы, L-аспартат: 2-оксоглутарат аминотрансферазы, L-аланин: 2-оксоглутарат аминотрансферазы, лактатдегидрогеназы, малатдегидрогеназы, $\alpha$-кетоглутаратдегидрогеназы и глутаматдегидрогеназы в митохондриальной и микросомально-цитозолевой фракциях слизистой рубца и печени. Дискутируется органная и субклеточная специфичность тканевого метаболизма, в котором слизистая оболочка рубца выполняет особую роль под действием кормового фактора, в том числе и йонофора.

\section{References}

ARMSTRONG, J. D. - SPEARS, J. W.: Intravenous administration of ionophores in ruminants: Effects on metabolism independent of the rumen. J. Anim. Sci., 66, 1988: $1807-1817$

BENZ, D. A. - BYERS, F. M. - SCHELLING, G. T. - GREENE, L. W. - LUNT, D. K. SMITH, S. B.: Ionophores alter hepatic concentrations of intermediary carbohydrate metabolites in steer;. J. Anim. Sci., 67, 1989: 2 393-2 399

BERGEN, W. G. - BATES, D. B.: Ionophores: Their effect on production efficiency and mode of action. J. Anim. Sci., 58, 1984: 1 465-1 483

DAVISON, K. L.: Monensin absorption and metabolism in calves and chickens. J. Agric. Food Chem., 32, 1984: $1273-1277$

ELLIOT, W. H.: Glutamine synthesis. In: Methods in Enzymology, Vol. II, 1955, pp. 337-342, Academic Press, Inc., New York 
FEGEROS, K.-PAPADOPOULOS, G.-ZERVAS, G. - ZIRAS, E. - CAFANTARIS, B.: Effect of lasalocid sodium and molases on performance of fattening lambs and on rumen liquor and blood parameters. Arch. Anim. Nutr., Berlin, 39, 1989: 921 - 931

GREENBERG, D. M.: Arginase. In: Methods in Enzymology, Vol. II, 1955, pp. 368-374, Academic Press, Inc., New York

GRINGS, E. E.-MALES, J. R.: Performance, blood and ruminal characteristics of cows receiving monensin and a magnesium supplement. J. Anim. Sci., 66, 1988: 566-573

GRISOLIA, S.: Enzymatic citrulline synthesis. In: Methods in Enzymology, Vol. II, 1955, pp. 350-355, Academic Press, Inc., New York

HOGEBOOM, G.: Fractionation of cell components of animal tissues. In: Methods in Enzymology, Vol. I, 1955, pp. 16-19, Academic Press, Inc., New York

KAUFMAN, S.: $\alpha$-Ketoglutaric dehydrogenase system and phosphorylating enzyme from heart muscle. In: Methods in Enzymology, Vol. I, 1955, pp. 714-722, Academic Press, Inc., New York

KORNBERG, A.: Lactic dehydrogenase of muscle. In: Methods in Enzymology, Vol. I, 1955, pp. $441-443$, Academic Press, Inc., New York

MAROUNEK, M. - PETR, O.-MACHÁŇOVÁ, L.: Effect of monensin on in vitro fermentation of maize starch by hindgut contents of cattle. J. Agric. Sci. (Camb.), 115, 1990: 389-392

MAROUNEK, M. - SKŘIVANOVÁ, V. - MACHÁŇOVÁ, L.: Effect of monensin on digestibility of nutrients, ruminal volatile fatty acids and blood parameters in young calves. Landwirtsch. Forschung, 42, 1989: 273-280

MORTON, R. K.: Methods of extraction of enzymes from animal tissues, In: Methods in Enzymology, Vol. I, 1955, pp. 25-51, Academic Press, Inc., New York

OCHOA, S.: "Malic” enzyme. In: Methods in Enzymology, Vol. I, 1955, pp. 739-753, Academic Press, Inc., New York

PRESSMAN, B. C. - FAHIM, M.: Pharmacology and toxicology of the monovalent carboxylic ionophores. Ann. Rev. Pharmacol. Toxicol. 22, 1982: 465-490

STRECKER, H. J.: L-Glutamic dehydrogenase from liver. In: Methods in Enzymology, Vol. II, 1955, pp. 220-225, Academic Press, Inc., New York

VAN RYSSEN, J. B. J.: Effect of monensin and its metabolites in broiler litter on sheep consuming the broiler litter. J. South Afr. Vet. Assoc., 62, 1991: 94-99 